\title{
Autoethnography, Autobiography, and Creative Art as Academic Research in Music Studies: A Fugal Ethnodrama
}

\author{
Christopher Wiley \\ University of Surrey, UK
}

Constructed broadly according to the principles of musical fugue, this piece of creative writing is presented as a performance autoethnography, enacted through a multi-voiced ethnodrama between a fictionalized version of the author and two imaginary doctoral students. In successive episodes, it discusses the difference between autoethnography and autobiography, the value and limitations of single-subject ethnographic study, and the types of materials that constitute valid documentation for the purposes of autoethnography, including creative writing based on music-theoretical devices as well as musical works themselves, in addition to more conventional modes of discourse. These dialogic interludes are articulated by periodic returns to the principal subject of the conversation: the working definition of autoethnography and its potential application to ArtsBased Educational Research (ABER) with specific respect to music studies.

Keywords: autoethnography, ethnodrama, music, creative arts, autobiography, ethnography, practice as research, single-subject study, arts-based educational research

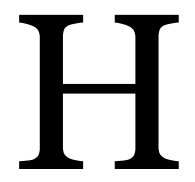

ow does autoethnography differ from autobiography, and from practice-based research? Under what circumstances, if any, is it genuinely useful-or even appropriate-for an author to narrate stories about themselves (or others) within the context of an academic study? Why might scholars wish to retell such anecdotes, or readers to engage with them? Or might such endeavors risk lowering the intellectual bar of original research to a level seen as narcissistic and unerudite, subject to significant critical onslaught on popular social media (as admirably discussed by Campbell 2017) and derided by one recent

(C) Christopher Wiley. The content of this article is the sole responsibility of the author. The ACT Journal and the Mayday Group are not liable for any legal actions that may arise involving the article's content, including, but not limited to, copyright infringement. 
$B B C$ News article as "a high-brow version of taking selfies, watching reality television and posting thoughts into the echo chambers of social media" (Pickles 2017)? Can autoethnographic documentation adopt more unconventional literary formssuch as narrative fiction, creative non-fiction, ethnodrama, or poetry-or even non-text-based creative practice outputs such as visual art or music composition? And would such an undertaking be any more or less desirable than an autoethnography written in familiar academic prose, or, for that matter, than a traditional research-oriented article?

The following text seeks to provide a personal-and autoethnographic-response in which these headline questions are explored. Written creatively as a dialogue between a fictionalized version of myself and two imaginary PhD students, Anna and Ed, it presents what Gouzouasis et al. (2014) have termed a "multivoiced performance autoethnography," and takes the form of an ethnodrama, a medium that has previously been successfully adopted elsewhere in Arts-Based Educational Research (ABER) (e.g. Gouzouasis and Bakan 2018; Gouzouasis, Henrey, and Belliveau 2008). While rooted in analogous modes of discourse such as duoethnography (Norris, Sawyer, and Lund 2012), collaborative autoethnography (Chang, Ngunjiri, and Hernandez 2013), and reciprocal autoethnography (Wiley and Franklin 2017), my work differs from previous writings in ABER in that it is entirely invented; in that respect it is the diametric opposite of precursors such as Gouzouasis and Bakan (2018), which essentially presents a polished transcript of selected real-life discussions. While the characters of doctoral candidates Anna and Ed are not intended to represent any single person, inevitably the ground set out in this article is indebted to a range of conversations over the years with academic colleagues-staff as well as students-in which the arguments presented below have been thoroughly rehearsed. ${ }^{1}$ In postmodern vein, the dramatis personae occasionally jump out of the diegesis in pursuit of wider academic points, including reference to the ethnodrama itself as well as to this explanatory preface, about which they could not possibly be aware. Being the real-life originator of all three voices, ultimately each represents different facets of my own thinking on this whole avenue of enquiry, the imaginary Anna and Ed self-reflexively functioning rhetorically to prompt me explicitly to question my own assumptions at every turn. For this reason, only limited attempts have been made to distinguish between the three characters linguistically.

Wiley, Christopher. 2019. Autoethnography, autobiography, and creative art as academic research in music studies: A fugal ethnodrama. Action, Criticism, and Theory for Music Education 18 (2): 73-115. http://dx.doi.org/10.22176/act18.2.73 
In devising this ethnodrama, I have consciously endeavored to adapt and apply the principles of a specific music-compositional procedure, fugue, mindful of previous examples of "fugal" creative writing in relation to ABER including Gouzouasis and Lee (2002) and Lee (2006), albeit constructed in markedly different ways from my own. The practice has a larger scholarly basis still: for instance, Wood (1993) put forward a stimulating argument for an understanding of selected passages from Ethel Smyth's autobiographical writings using the metaphors of fugue and counterpoint; my own work on the rhetoric of the great male musical genius and their associated female muse (Wiley 2017) draws upon the analogy of "subject" and "countersubject" in discussing the figure at the center of a biographical text (commonly called the "subject" in literary studies) in relation to the secondary characters intertwined within their life narratives. In literary theory and philosophy, Bakhtin (1984) invoked the musical metaphor of polyphony, with specific respect to Dostoevsky's writings, in developing the notion of heterogenous dialogic "voices" operating simultaneously within narratives that eschew the singularity of a unified authorial presence.

These precedents are among the various reasons governing my choice to draw upon the principles of fugue (with a certain amount of artistic license exercised, not least because one cannot realistically hold a conversation in which everybody is speaking simultaneously, and because the character of the fictionalized author necessarily leads discussion at key structural points) rather than, say, sonata form or rondo form. Fugue, as one of the most extensively practiced compositional procedures in the history of Western art-music from the Middle Ages to the present, represents the epitome of polyphony: multi-voiced music conceived primarily "horizontally" rather than "vertically," its different parts coalescing with one another according to defined principles of counterpoint, such that every one is imbued with broadly equal weight and independent melodic interest. Each of the three or more parts, or "voices," in a fugue presents in turn the "subject"-the central musical theme, from which much of the entire work is ultimately derived-at specific intervals apart; following the initial presentation of the subject unaccompanied in the first voice, a second voice then enters with the "answer," comprising the subject normally at the fifth rather than the octave (often in modified form to preserve the tonality of the music), against which the first voice presents a "countersubject" that may be heard in successive parts upon the subsequent entrance of the third and any further voices. After the subject (or answer) has been presented

Wiley, Christopher. 2019. Autoethnography, autobiography, and creative art as academic research in music studies: A fugal ethnodrama. Action, Criticism, and Theory for Music Education 18 (2): 73-115. http://dx.doi.org/10.22176/act18.2.73 
by each voice in turn during the fugal "exposition," together with linking codettas as required, the music may thereafter continue to unravel through "episodes" (typically reworking material from the subject and/or countersubject, each such passage functioning to modulate from one closely related key to another, and often thinning the texture through a reduction in the number of active voices), re-entries or "middle entries" of the subject and/or answer (together with, possibly, a "redundant entry" immediately following the fugal exposition), "strettos" (in which, during a middle entry, the subject appears in a second voice before the first voice has finished), and other devices such as augmentation, diminution, or inversion of the subject, before finally returning to the home key for one final entry of the subject in the coda. Each voice is therefore afforded opportunities to present the subject and to respond to it, to lead and to follow, while the parts combine, intertwine, and trade places with one another, potentially also peeling off into smaller clusters before reconstituting the full grouping. Fugue therefore presents itself as a form well suited to the exploration of specific points (and counterpoints) in a piece of discursive writing, enabling periodic returns to the principal subject under consideration by way of reviewing and reiterating the central arguments, while the advancement of discussion finds an analogue in the changes of key effected by the interlinking episodes.

Originally conceived as a conventional script, with each line of dialogue extending across the width of the page, ultimately I opted for a landscape-format three-column presentation in which the impression of three parallel and equivalent voices, which fill in the space between one another's lines as in a musical fugue, is more effectively conveyed visually (even if the analogy to a standard Western musical score, which is read from left to right rather than top to bottom, remains limited). For the benefit of readers not versed in fugal procedures, and in the hope that future authors may continue to capitalize upon the creative potential of different music-compositional processes as methods by which to explore autoethnographic perspectives through creative writing, specific structural sections are indicated using emboldened text in square brackets so as to illuminate the fugal aspects of the whole. Occasional stage directions are rendered in italics and square brackets, and, while unconventional for scripted dialogue, bibliographic references have been parenthetically edited into the below text by way of identifying the ways in which my thinking has been guided by, and may be situated within, wider scholarly debates.

Wiley, Christopher. 2019. Autoethnography, autobiography, and creative art as academic research in music studies: A fugal ethnodrama. Action, Criticism, and Theory for Music Education 18 (2): 73-115. http://dx.doi.org/10.22176/act18.2.73 


\section{CHRIS}

\section{[Introduction]}

Anna, Ed, I thought it might be helpful to have a three-way conversation about autoethnography, as I know that we're all grappling with similar issues in our research, such as the difference between autoethnography and autobiography, how to use autoethnographic methods to talk about yourself appropriately within academic discourse, and the different forms that autoethnography might take. But shall we get started by introducing the areas we are researching at the moment and how they relate to our own personal experiences? Perhaps if I go first?

\section{[Fugal exposition: Subject]}

I've discussed my own experiences, and used myself as a case study, primarily in my published writings on education. Initially, I did not explicitly frame my work as autoethnography, although the methods I was using were similar (Wiley 2014a). Then my colleague, Ian, suggested that I investigate autoethnography as a possible scholarly

framework I might find valuable to use, and I immersed myself in the literature on the subject, particularly in relation to pedagogic research (Wiley, in review). My recent work in the field includes a collaboration with Ian

ANNA

ED

Wiley, Christopher. 2019. Autoethnography, autobiography, and creative art as academic research in music studies: A fugal ethnodrama. Action, Criticism, and Theory for Music Education 18 (2): 73-115. http://dx.doi.org/10.22176/act18.2.73 
(Kinchin and Wiley 2018) in which he functions as interviewer with myself as autoethnographic subject, as well as an essay written with my friend Jo (Wiley and Franklin 2017), which we constructed as a "reciprocal autoethnography," such that we both function simultaneously as interviewer and interviewee. Anna, do you want to go next?

\section{[Countersubject]}

So you, and your performance-related activity, constitute an integral part of your research, almost by definition?

\section{[Answer]}

Thank you, Chris. As you know (but Ed may not), my project combines my practical studies of ensemble violin-playing in a classical string quartet with major historical and analytical research into the works in our repertoire.

That's correct, and in consequence I've been thinking a great deal lately about various issues of practice-based research in relation to my own experiences as a researcher-performer, for instance: whether undertaking scholarly research into a work necessarily enhances a performance (and vice versa, for that matter), how it might be manifested in a recital and readily detected by the audience member, and how it could be articulated within the written commentary of my dissertation. As I'm only partway through the 


\section{[Codetta]}

...but that doesn't mean that your views are any less 'valid' per se. It's important to remember that the $\mathrm{PhD}$ is (or should be) an apprenticeship for the academic profession (Park 2007)-and that the current trend in the UK higher education sector is for students and staff to be considered as being in partnership with one another (Healey, Flint, and Harrington 2014).

I've no doubt that you will! You too, Ed.

$\mathrm{PhD}$, my work is more formative, and of course I haven't published anything yet...

Indeed, and I do hope to publish someday.

\section{[Countersubject]}

So, that's how your work relates to your own personal experience, then?

\section{[Subject]}

Thanks! You're both familiar with my work already, but just to recap, I'm a singer-songwriter whose music reflects my own autobiographical experiences. I'm intending to write about my personal motivation and the meaning behind my songs so that the listener understands what they're all about.

Therein lies my problem. I'm struggling to find ways of talking about my songs without giving a long discussion of my autobiography, and the events in my life that 


\section{[Codetta to fugal exposition]}

That's an excellent place to start our discussion.

\section{[Redundant entry: answer]}

Quite right, I was. Now that we've all introduced ourselves and our areas of research, the logical next step would be to introduce autoethnography itself. When I talk about "autoethnography," I understand it to refer to a specific methodology that draws upon the author's own (autobiographical) experiences

precipitated it. Is that all I have to do, tell a story about myself, and call it "autoethnography"? Could I really get the $\mathrm{PhD}$ that way? Surely there's more to scholarship than writing my own life story. My housemates in the mainstream science disciplines already think that I'm taking a "soft" subject; I wouldn't want to give them any more ammunition with which to fuel the daily banter (all of it good-natured, you understand) about my doctorate not being worth as much as theirs.

By talking about whether science PhDs are valorized above parallel degrees in the arts and humanities?

Wiley, Christopher. 2019. Autoethnography, autobiography, and creative art as academic research in music studies: A fugal ethnodrama. Action, Criticism, and Theory for Music Education 18 (2): 73-115. http://dx.doi.org/10.22176/act18.2.73

[laughs] That might be the subject of an altogether different conversation, which we can have with my science pals over a pint or two sometime! I think Chris was referring to the difference between autoethnography and autobiography. 
in order to yield an enhanced understanding of both the sociocultural context in which the autoethnographic subject is located, and his or her relationship to that context (e.g., Etherington 2004; Austin and Hickey 2007; Ellis, Adams, and Bochner 2011). Chang (2008, 49-50) says, "autoethnography is not about focusing on self alone, but about searching for understanding of others (culture/society) through self;" Ellis and Bochner (2000, 739) that "autoethnographers gaze, first through an ethnographic wide-angle lens, focusing outward on social and cultural aspects of their personal experience; then, they look inward, exposing a vulnerable self that is moved by and may move through, refract, and resist cultural interpretations." After all, autoethnography has its roots in ethnography: the writing about people, cultures, communities, societies, or tribes. And, as Becher and Trowler (2001) indicate, academia has its "tribes" much like any culture.

Sure: my autoethnographic study of my undergraduate module on Adele's 25 album (Wiley, in review) draws upon narratives of my experiences teaching that one module as a lens through which to understand higher education popular music, and the relationship

\section{[Countersubject]}

Could you maybe give us a "real life" example?

Wiley, Christopher. 2019. Autoethnography, autobiography, and creative art as academic research in music studies: A fugal ethnodrama. Action, Criticism, and Theory for Music Education 18 (2): 73-115. http://dx.doi.org/10.22176/act18.2.73 
between teaching and research, in the contemporary UK academic profession more widely. In addressing the broader contexts via a single case study, autoethnography thereby goes beyond mere autobiography (e.g. Belbase, Luitel, and Taylor 2008;

Vasconcelos 2011). I think of it as "autobiography plus," or "autobiography with references," by which I mean autobiography that is robustly embedded within scholarly discourses, rather than literally autobiography with a few footnotes added. Although I accept that the importance I place on robustly grounding autoethnography in existing academic literature is only implicit in my working definition.

Ah...remember that as a PhD student, you are writing a thesis, which, etymologically, stems from the Greek thésis (Өغ̇oı) meaning a "position" or "proposal." (Particularly in the UK, it is common to refer to one's PhD dissertation as a "thesis.") Presenting aspects of your own life story would be interesting, I'm sure, but this alone would lack the position that is crucial to meeting the requirements of your

\section{[First episode]}

[laughs respectfully] Yes, I was just about to mention that! So I can't just write an autobiographical narrative and have the reader figure out for themselves my relationship with the cultural context to which I belong?

Wiley, Christopher. 2019. Autoethnography, autobiography, and creative art as academic research in music studies: A fugal ethnodrama. Action, Criticism, and Theory for Music Education 18 (2): 73-115. http://dx.doi.org/10.22176/act18.2.73 
dissertation: the advancement of knowledge and scholarship in the discipline.

[embarrassed smile] You're quite correct! And it's worth mentioning that there are many different modes of self-narration: autobiography, storytelling, life-writing, self-reflection, self-observation, narrative inquiry, and so on. I suppose I'm particularly sensitive to this point, given that much of my musicological work outside of pedagogic research also concerns biography and lifewriting (e.g. Wiley 2008; Wiley forthcoming). For me, whether a study constitutes "autoethnography" is fundamentally a question of how the data is framed and presented, how it is used in relation to the main argument, and how it is located within larger scholarly debates. Part of the challenge comes with integrating the two, while avoiding the crunching gear-changes resulting from alternating sections of autobiography and autoethnography (although there is plenty of autoethnography written this way too).
Right, but weren't you saying just now that the PhD should be an apprenticeship for the profession, and that Anna and I should be aspiring to publication beyond simply writing the dissertation (or words to that effect)?
How would you suggest that I endeavor to "frame and present" my information, then, in order for it to be recognized (and

Wiley, Christopher. 2019. Autoethnography, autobiography, and creative art as academic research in music studies: A fugal ethnodrama. Action, Criticism, and Theory for Music Education 18 (2): 73-115. http://dx.doi.org/10.22176/act18.2.73 
Well, there's a world of difference between merely telling a story, and using it as a means of understanding the culture of which the storyteller is a part. For instance, I often encounter undergraduates who propose to tell personal narratives about their relationships as fans to their favorite artists for their popular music studies coursework. I tend to tell them that they would be very welcome to situate their stories within existing academic studies of fandom as a means of illuminating the wider cultural context in which they are situated-but that such a project would be quite challenging to bring to fruition in practice. Conversely, if they just want to write about how much they admire a given singer or band, then they're unlikely to meet the learning outcomes for their module, which are geared strongly towards the academic study of popular music.

I think it can be very interesting, and illuminating, to give some of these insights, provided that they are kept in check (confined to

recognizable) as autoethnography rather than autobiography?
But I really want people to understand the personal circumstances underpinning my songs. Are you hinting that it's not important for the reader to be told about an author's motivation and where they are "coming from"?

Wiley, Christopher. 2019. Autoethnography, autobiography, and creative art as academic research in music studies: A fugal ethnodrama. Action, Criticism, and Theory for Music Education 18 (2): 73-115. http://dx.doi.org/10.22176/act18.2.73 
an introduction or foreword, for example). But again, it's a question of how you use the information. If you do little more than serve it up for the reader, then that's autobiography. To elevate your work to the level of autoethnography, it would need, at least implicitly, to take its lead from ethnography in terms such as ethical considerations, modes of data-gathering, evaluation and interpretation of the evidence, and so forth, in order to explicate the individual's relationship to their cultural context.

It's more a question of the relatability of the story you have to tell, and how strongly it resonates with the reader who engages withand thereby interprets and validates - the text. Some of the "interviews" you are describing may be recognized as autoethnography, while others won't. My hope is that autoethnography doesn't follow the same trend as ethnography, which is becoming a rather over-used, misused, and even abused term in contemporary academe. Ingold (2014) has persuasively argued that ethnography is, or should be, more than (say) conducting interviews, and that it has become infelicitously disconnected from its anthropological grounding in participant observation. That said, it's also important to acknowledge

So can I just conduct an "interview" with myself and call it autoethnography?

Wiley, Christopher. 2019. Autoethnography, autobiography, and creative art as academic research in music studies: A fugal ethnodrama. Action, Criticism, and Theory for Music Education 18 (2): 73-115. http://dx.doi.org/10.22176/act18.2.73 
that ethnography is not the same thing as participant observation either (Hockey and Forsey 2012).

Right, and that potentially makes the question of personal motivation relevant as autoethnographic data. As my own doctoral supervisor helpfully once said to me, one has to recognize the difference between what is relevant and what is merely interesting. And of course the latter should be excised from your work: you should tell the reader only what information they need to know in order to follow your line(s) of enquiry. In the context of autoethnography, this means supplying the materials required to retell a story that will truly resonate with the reader (but without giving them so much detail that they cannot see the proverbial wood for the trees). Banks and Banks (2000, 236) comment, "we might write so as to invite readers to share our emotional responses to our professional activities and their consequences." Conversely, providing information that you wish
Fair enough. So, if I'm recounting a story as a "hook" to engage the reader, or to provide some background on myself as an author, then that's not autoethnography. But if I'm using it as a point of departure in order to undertake rigorous scholarly evaluation of the contemporary popular music scene more broadly, then it might be autoethnography?

Wiley, Christopher. 2019. Autoethnography, autobiography, and creative art as academic research in music studies: A fugal ethnodrama. Action, Criticism, and Theory for Music Education 18 (2): 73-115. http://dx.doi.org/10.22176/act18.2.73 
to volunteer even though it isn't pertinent to discussion can be counterproductive: it will likely weaken your work by diluting the writing with material that doesn't contribute directly to your arguments, thereby compromising its relatability to the reader and dulling the impact of the narrative you offer. Less is sometimes more (which is something else my doctoral supervisor used to say to me). You should continually ask yourself, "so what?" and if you can't answer that question about some of the information you provide, perhaps it doesn't have a place in your work after all.

\section{[Middle entry: subject]}

"So what?" is a great question to ask oneself in relation to an academic author telling stories about themselves, whether to lay the foundations for autoethnography or to fulfil another function. You said it yourself, Chris-why should anybody else want to know about, for example, the personal motivation behind Ed's songs? This whole line of enquiry speaks to some concerns I have about the value of autoethnography that I was hoping to bring up in the course of this meeting. I don't mean to be impertinent in mentioning all of this,

Wiley, Christopher. 2019. Autoethnography, autobiography, and creative art as academic research in music studies: A fugal ethnodrama. Action, Criticism, and Theory for Music Education 18 (2): 73-115. http://dx.doi.org/10.22176/act18.2.73

\section{[Countersubject]}

-please don't fret on my account; I'm not entirely "sold" on the concept of autoethnography (yet) either. 
That's a question that I've been asking myself as well, as I've turned increasingly to different forms of autoethnography in my pedagogic research. One of my published studies on learning and teaching in higher education even explicitly acknowledged "the difficulty of making general statements about an area as vast as the arts [disciplines] based on a single comparative case study" (Wiley and Franklin 2017, 27). I'm reminded of that apocryphal Indian fable, in which several blind (or blindfolded; it depends which version you read)

—which I most certainly am not (!) - -is only a small part. They might not even be particularly representative of that culture to begin with.

\section{[Second episode]}

Chris, given that you said earlier that autoethnography has its roots in ethnography, and is therefore related to writing about a culture or community, I'm wondering how an ethnography can result from a scholarly retelling of one person's story?

Wiley, Christopher. 2019. Autoethnography, autobiography, and creative art as academic research in music studies: A fugal ethnodrama. Action, Criticism, and Theory for Music Education 18 (2): 73-115. http://dx.doi.org/10.22176/act18.2.73 
men each examine an elephant. No doubt you've heard of it: one member of the group feels the elephant's leg, and surmises that the animal must be like a tree-

-and so on. Each of the men is correct, but none of them is able to construct a complete picture of the elephant from the partial context they have investigated. As regards autoethnography, what matters is not so much the generalization and generalizability of one individual's stories, so much as their relatability: whether the narratives that are told resonate with the readers who engage with them, and who may thereby generalize them to other situations beyond the context of the original study-a little like recognizing the elephant by relating to the description of the tree, or spear, or, rope. But I totally understand why autoethnography presents itself as an unusual methodology-at face value, it would seem to be the complete opposite of much social science research, which seems to place a premium on a large sample size in relation to the overall population, to establish credibility and statistical significance for the findings as well as to minimize the effect of -while another touches the point of the tusk, and supposes the elephant to be like a spear- -and a third feels its tail, and hence believes it to be like a rope-

Wiley, Christopher. 2019. Autoethnography, autobiography, and creative art as academic research in music studies: A fugal ethnodrama. Action, Criticism, and Theory for Music Education 18 (2): 73-115. http://dx.doi.org/10.22176/act18.2.73 
any potential outliers among the study respondents.

Ah, but part of the academic value of autoethnography lies in its very conflation of author and subject. It enables a more personal, familiar, and emotional-not to mention subjective, as well as diverse-dimension to come across than would normally be the case in ethnographic study, or indeed much academic writing (e.g., Pelias 2004; Pelias 2005; Ellis, Adams, and Bochner 2011; Bochner and Ellis 2016). Ellis $(2012,135)$ has written evocatively of "the challenge of convincing the academic world that introspective ethnography should be included in sociology and could meet the criteria of rigorous inquiry," with respect to her work in the later 1980 s. It's also worth noting that single authorship isn't the only way of going about autoethnography: Chang, Ngunjiri, and Hernandez (2013) advocate "collaborative autoethnography" across a given research team, for example, while Anderson (2006) suggests that
And I see this issue as doubly problematic in autoethnography, in which the author is acting as their own informant, writing about themselves without the benefit of an independent researcher to function as a more impartial observer able to mediate their views more objectively with the benefit of greater critical distance.

Wiley, Christopher. 2019. Autoethnography, autobiography, and creative art as academic research in music studies: A fugal ethnodrama. Action, Criticism, and Theory for Music Education 18 (2): 73-115. http://dx.doi.org/10.22176/act18.2.73 
interviewer and autoethnographic subject should be named as co-authors in the published research. I've employed various different means of constructing an autoethnography in my own output: acting as interviewee (Kinchin and Wiley 2018), interviewer (Wiley and Franklin 2017), and sole author (Wiley, in review), depending on which I feel to be the most effective format for a given study.

Indeed I haven't-and I'm not sure that I really have a response, since autoethography has evolved considerably since its early roots in anthropology and ethnography. What I would say is that, as Richardson (1990) has explored, the audience-and writing for one's audience-is key to a successful autoethnography: whether the reader can genuinely relate to the study presented is a primary validating criterion. Ellis, Adams, and Bochner $(2011,10)$ have noted that "In autoethnography, the focus of generalizability moves from respondents to readers, and is always being tested by readers as they determine if a story speaks to them about their experience or about the lives of others they know;" Pelias (2014) even called for a reconceptualisation of the act of reading along more critically reflective lines in connection

Chris, forgive me, but I'm not sure that you've quite addressed Anna's point yet.

Wiley, Christopher. 2019. Autoethnography, autobiography, and creative art as academic research in music studies: A fugal ethnodrama. Action, Criticism, and Theory for Music Education 18 (2): 73-115. http://dx.doi.org/10.22176/act18.2.73 
with autoethnographic writing. It's also important to remember, recalling the working definition I alluded to earlier, that autoethnography concerns the relationships between the subject and the culture in which he or she operates. That much is by definition personal to an individual, and the evaluation yielded by the autoethnographic study-and its situation within the scholarly discourse-will provide the author (as the subject of their own autoethnographic research) with the opportunity to identify the extent to which they are representative of the totality of their culture. For that matter, subjects that are distinctive for being unrepresentative might nonetheless be highly illuminating as autoethnographic case studies, precisely for the ways in which they stand in contrast to the mainstream of the context in which they operate.

\section{[Countersubject]}

Of course; I was hoping that we'd go back to it in the course of discussion. What did you have in mind in particular?

\section{[Middle entry: subject] \\ I wonder if we might revisit your working definition at this juncture. \\ Well, Chris, while you have indicated that the reader-and the relatability of the study to the reader-are important to an autoethnog- raphy, at the same time you have spoken us- ing the terms of ethnographic fieldwork with}

Wiley, Christopher. 2019. Autoethnography, autobiography, and creative art as academic research in music studies: A fugal ethnodrama. Action, Criticism, and Theory for Music Education 18 (2): 73-115. http://dx.doi.org/10.22176/act18.2.73 
Again, it depends on how you as the author

\section{[Stretto: answer]}

-but what exactly are these materials, and what constitutes "data" for the purposes of autoethnographic research?

For instance, since my research project is largely based on my rehearsals with my string quartet, inevitably I'm going to be talking about myself a significant amount in my dissertation. I couldn't do otherwise and still call my work practicebased research. I'll be exploring my experiences primarily using self-narration, drawing on the detailed rehearsal diaries that I already maintain for this very purpose, triangulating my findings through interviews with the other members of my quartet.

\section{[Third episode: an inversion of the first} episode]

Given the documentation on which I'm drawing, do the practices I've outlined count as autoethnography? your references to "data-gathering," "ethical considerations," "materials," and so on-

\section{[Countersubject]}

Thank you, Anna-my thoughts exactly!

use this information. My friend Kirk has encouraged me to think carefully about the important distinction between different forms of research informed by practice: practice as 
research, practice-based research, and research about practice.

To my mind, your methodology seems most consonant with practice as research (Nelson 2013), given that your practice is an integral part of your research, without which you effectively wouldn't have a project. Were you rehearsing the music as a means of better understanding it for the purposes of undertaking an analytical study, say, then that might be better described as practice-based research. Whereas if your dissertation primarily comprised a written account of the ground covered in your rehearsals, I'd call that research about practice. But in reality these terms tend to be quite fluidly used. It certainly didn't cause my eyebrows to raise when you referred to your work earlier as "practicebased research," since your research has a clear basis in your practice.

To a greater or lesser extent, that must logically be true. The value of methodologies such as practice as research and autoethnography is that the position of the author in relation to his or her research is made so explicit. Were it not for the author's undertaking research about themselves, as I say,

Out of curiosity, which do you think describes my study best?

But isn't every author implicated in their own writing?

Wiley, Christopher. 2019. Autoethnography, autobiography, and creative art as academic research in music studies: A fugal ethnodrama. Action, Criticism, and Theory for Music Education 18 (2): 73-115. http://dx.doi.org/10.22176/act18.2.73 
they wouldn't have a study to begin with. This exists in sharp contrast to much ethnography, for which practitioners have needed to make a concerted effort to factor into their work the ways that their very presence can affect the subjects of their research and hence skew their findings. I don't subscribe to Jackson's (1989) claim that observation yields objective data and participation subjective data; I'm more inclined towards Ingold's (2014, $387-8$ ) view that "there can be no observation without participation," which leads to an understanding of all ethnography as being subjective.

Well, I've drawn upon case studies from my teaching in much of my pedagogic research, even the studies that have no relationship to autoethnography (e.g., Wiley 2014b; Wiley, 2015). But in other instances, my authorial presence has been strikingly absent: for example, an anonymous peer reviewer for one of my earliest musicological articles (Wiley 2004) remarked that it was peculiar for what was essentially a study of autobiography to be itself devoid of autobiographical context.

Truth be told, I wasn't comfortable supplying that context since I felt that the study wasn't about me, so much as being about Ethel Smyth and Virginia Woolf. (I was even more

May I ask how you see yourself in your own work, then?

Wiley, Christopher. 2019. Autoethnography, autobiography, and creative art as academic research in music studies: A fugal ethnodrama. Action, Criticism, and Theory for Music Education 18 (2): 73-115. http://dx.doi.org/10.22176/act18.2.73 
uneasy about the potential subtext there: whether I had any business at all in conducting research within women's and lesbian studies when I obviously do not fall into either category.) Then, of course, there are the inevitable "in jokes"-for instance, at one point in a book chapter on television and film music (Wiley 2011, 34) I wanted to make reference to a couple of early (silent-era) serial films, and I couldn't resist choosing to name The Perils of Pauline as one of my examples.

I was amused by the title as "Pauline" is also the name of my mother! Anyway, I'm sure all writers include "in jokes" of this nature every now and then, wouldn't you have thought?

Not as it presently stands, but I'm not suggesting that you couldn't use autoethnographic methods in addition to undertaking practice as research. That might prove both innovative and enriching for your studyhence why I've been encouraging you to explore these different possibilities. In order to elevate your work to the level of autoethnography, however, I'd expect your writing to

I don’t get it?!

Hmm, I'm not sure-I'd have to ask my friend Rexie from Sociology, she'd know for sure! But Chris, if all work is ultimately a product of its writer, and that alone doesn't make it autoethnography, then perhaps my work isn't autoethnography at all?

Wiley, Christopher. 2019. Autoethnography, autobiography, and creative art as academic research in music studies: A fugal ethnodrama. Action, Criticism, and Theory for Music Education 18 (2): 73-115. http://dx.doi.org/10.22176/act18.2.73 
yield some sense of the interplay between the particular and the general, such that the relationship comes across between the specific context of your rehearsals and the wider cultural framework in which you are locatedfor instance, the performance of Western artmusic in the twenty-first century by semiprofessional chamber groups, specifically, string quartets. As I say, you've effectively undertaken much of the ethnographic datagathering already, since you have systematically kept rehearsal diaries. For an autoethnography, you might seek to supplement these materials with other forms of documentation such as reflective narratives you have written, or interviews conducted between yourself and a friend whose role would be to provide you with suitable "prompts" to generate additional information. The video recordings that I know you have taken of your rehearsals might prove invaluable to an autoethnographic study as well-if you can bear to watch them back!

\section{[Middle entry: subject]}

Since you've just introduced audiovisual documentation into discussion, could we return to the question of the types of materials that might constitute valid data for the purposes of autoethnography?

Wiley, Christopher. 2019. Autoethnography, autobiography, and creative art as academic research in music studies: A fugal ethnodrama. Action, Criticism, and Theory for Music Education 18 (2): 73-115. http://dx.doi.org/10.22176/act18.2.73 


\section{[Countersubject]}

[smiles] I was hoping we might! And I think I know what you're going to ask, too.

Well put; that's exactly the direction I hoped our discussion would take. The simple answer is that it would certainly be innovativeand, as you indicate, non-conventional-but that I see no reason why autoethnography shouldn't draw on any of these types of materials in principle. For example, there are multiple precedents for studies of ABER being creatively written according to various

Thus far, you've only made reference to traditional written (and video-recorded) forms of ethnographic documentation. But I was curious to know whether it might be acceptable to draw upon other, less conventional materials for an autoethnography as well. I was even wondering if my songs might themselves constitute autoethnography-not an autoethnography of the music, so much as music as autoethnography-or, at the very least, whether the lyrics might be "fair game" for an autoethnographic study.

\section{[Fourth episode]}

Would it hypothetically be viable for autoethnography to use, for instance, fictional discourses or creative artwork in addition to (or instead of) the kinds of materials more usually encountered in ethnographic research? 
principles of music composition: in addition to a number of fugal writings (e.g., Gouzouasis and Lee 2002; Lee 2006; this ethnodrama), each very differently constructed, Gouzouasis's (2008) investigation of validity in assessment takes the form of a tripartite Toccata whose sections are differently paced, with tempo instructions to match.

Definitely: music's compositional procedures are ideally suited to adaptation for creative writing exercises of this nature, and there is clear value in doing so, too. Gouzouasis $(2008,221)$ has observed that when employing a form such as fugue in creative writing, "our interpretations [a]re influenced by the form of the representation," which suggests that fresh knowledge may result from adopting innovative formats. We need not merely limit ourselves to fugue either. Sonata form would permit the juxtaposition of two conflicting ideas or "subjects," their subsequent development, and ultimately the resolution of the tension between them in the recapitulation section. Rondo form would facilitate periodic returns to the main subject, separated by contrasting, self-contained episodes that would allow ancillary issues to be explored. All that is needed are some exemplars to demonstrate how such undertakings might be

That's really interesting! Might there be scope for more work in this area?

Wiley, Christopher. 2019. Autoethnography, autobiography, and creative art as academic research in music studies: A fugal ethnodrama. Action, Criticism, and Theory for Music Education 18 (2): 73-115. http://dx.doi.org/10.22176/act18.2.73 
effected in relation to autoethnography, to enable others to follow (cf. Gouzouasis and Bakan 2018, 573).

I certainly could! Creative nonfiction, poems, ethnodrama, audiovisual art-I'd consider al of those, and more besides, to be valid as autoethnographic material. I think of it as rehabilitating the "Creative" in "Creative Analytical Practices," to use Richardson's (2000) term-or, if you prefer the short form, putting the "C" into "CAP." This, surely, is one area in which music studies-as undertaken both by musicologists and by practitioners-could lead the multi-disciplinary field of autoethnography by showing how different creative artforms might be used for these purposes. As I argue elsewhere (Wiley, in review), the arts and humanities would be particularly well-suited to engagement with non-conventional media such as fictional writing and audiovisual materials in relation to autoethnographic enquiry.
And recalling my earlier question about the autoethnographic status of my songs, could you envisage scenarios in which we might draw upon creative artwork in the writing of autoethnography?
But wouldn't it raise a number of additional challenges to make use of these kinds of nonconventional modes of discourse in autoethnographic work?

Wiley, Christopher. 2019. Autoethnography, autobiography, and creative art as academic research in music studies: A fugal ethnodrama. Action, Criticism, and Theory for Music Education 18 (2): 73-115. http://dx.doi.org/10.22176/act18.2.73 
Indeed it would-and some of these are purely practical, such as necessitating a specific layout for the text that the publishers may not be able to accommodate. Then there's the matter of the output needing to be simultaneously credible-and convincing-as artwork and as academic writing. That requires some compromises to be made in the text as well as a certain amount of artistic license to be exercised, since the language used for scholarly writing may be quite different from that for creative prose, or from the more colloquial register needed to give everyday conversation the air of authenticity. And some authors might understandably shy away from such innovative yet unconventional approaches to begin with, since they may have little prior experience of writing (say) creative fiction and so have concerns about the quality of the end product.

That's another question I've asked myself in the course of my engagement with autoethnography. In my first project explicitly utilizing this approach, I had originally planned to revert to fictitious examples in support of the points I pursued, intending them to have a strong basis in real-life episodes that I had witnessed in the course of my academic career but with certain details changed in order

And how can fiction, for instance, stand in place of real-life ethnography?

Wiley, Christopher. 2019. Autoethnography, autobiography, and creative art as academic research in music studies: A fugal ethnodrama. Action, Criticism, and Theory for Music Education 18 (2): 73-115. http://dx.doi.org/10.22176/act18.2.73 
to preserve a degree of distance and anonymity. But I soon came to realise that (to quote my own words) "while fictionalised or anonymised narrative is a recognised method in social science research, it felt counterintuitive to move away from the truth in an attempt to tell that truth" (Kinchin and Wiley 2018, 258). It seemed to me that if I started fabricating elements of my own stories rather than adhering strictly to the facts of my past experiences, the study would lose credibility.

[laughs] Hey, that's different! The purpose of this ethnodrama is to facilitate the discussion of general points related to the practice of autoethnography, enabling the views of the author to be rehearsed and debated. It isn't dependent on the fine detail of specific episodes in my career in higher education teaching, and makes no claims to offering them.

I don't know, to be honest; it wasn't my intention at all. My initial plans were for a tightly-written performance autoethnography, perhaps little more than double the [with irony] Not at all what you're doing here, then?

Wiley, Christopher. 2019. Autoethnography, autobiography, and creative art as academic research in music studies: A fugal ethnodrama. Action, Criticism, and Theory for Music Education 18 (2): 73-115. http://dx.doi.org/10.22176/act18.2.73

More to the point, isn't there an issue of interpretation when bringing some of these creative artforms into play as autoethnographic documents? Why, for example, did you deem it necessary to provide such an extended introduction to this ethnodrama? 
length of my introductory preamble. I had envisaged launching straight into the script immediately following the abstract. But even before I had started writing it, I came to realize that it was important that the ethnodrama component of this study be firmly embedded within the academic literature that had guided my thinking, and I didn't feel I could adequately do so solely by using in-text references within the script (which already extends the form beyond its usual parameters). Banks and Banks (2000) reached the same conclusion regarding the need for contextualization with respect to Pelias's (2000) experimental second-person autoethnography.

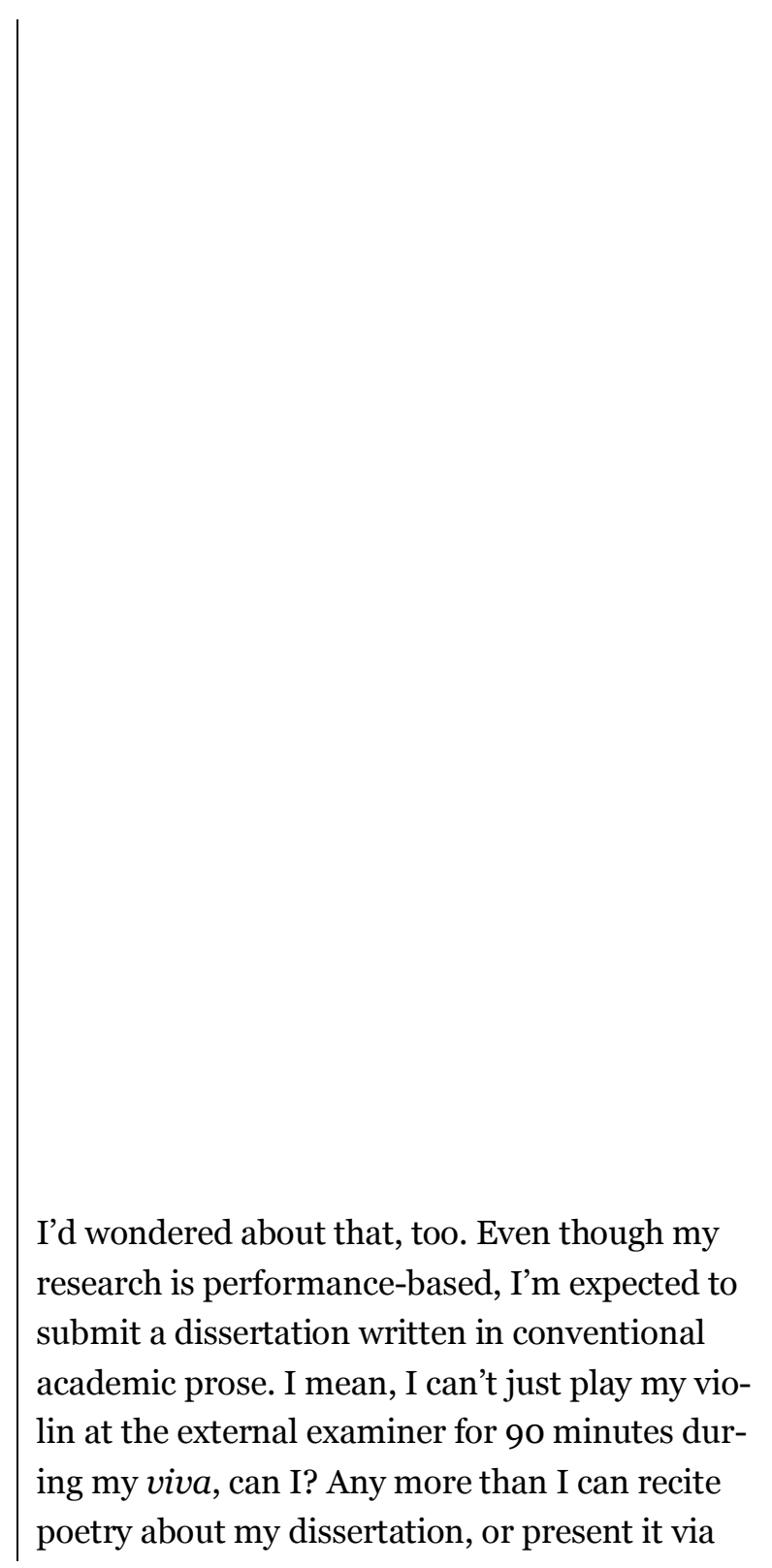

$$
\begin{aligned}
& \text { I } \\
& \text { Tor } \\
& \text { a } \\
& \text { wh } \\
& \text { a } \\
& \text { P } \\
& \text { Pad }
\end{aligned}
$$

To bring this argument back to music, there's a question on my mind about the extent to which a composition, for instance, may be accepted and understood as an act of research on its own terms (e.g., Croft 2015; Pace 2016), without an accompanying commentary to provide a more explicit context for the output as being research, hence strengthening its credentials in that area. 
[laughs] Perhaps some day. These are all excellent points, which might easily furnish the material for a follow-up meeting; it's a discussion that relates to your earlier question, Anna, about how your research might be manifested in your performance. What I would offer by way of a brief response is that the assumption that music requires explanation through words is nothing new-it has its roots in the modes of musical thinking prevalent in the nineteenth century. Cook (1998, 39) has expressed the point well in commenting that "as the word was eliminated from music, it began to fill the space around music," citing examples across the decades from programme notes to music appreciation texts to websites. He writes of "the basic model we retain today of how words should relate to music: by explaining it. The paradox lies in the fact that if music needs to be explained through words, then it must stand in need of explanation, must be in some sense incomplete without it." At the present time, then, we remain so indebted to these ways of conceptualizing music that textual commentaries are invariably required in order to locate the creative arts more explicitly within the scholarly debates they are intended to advance, as

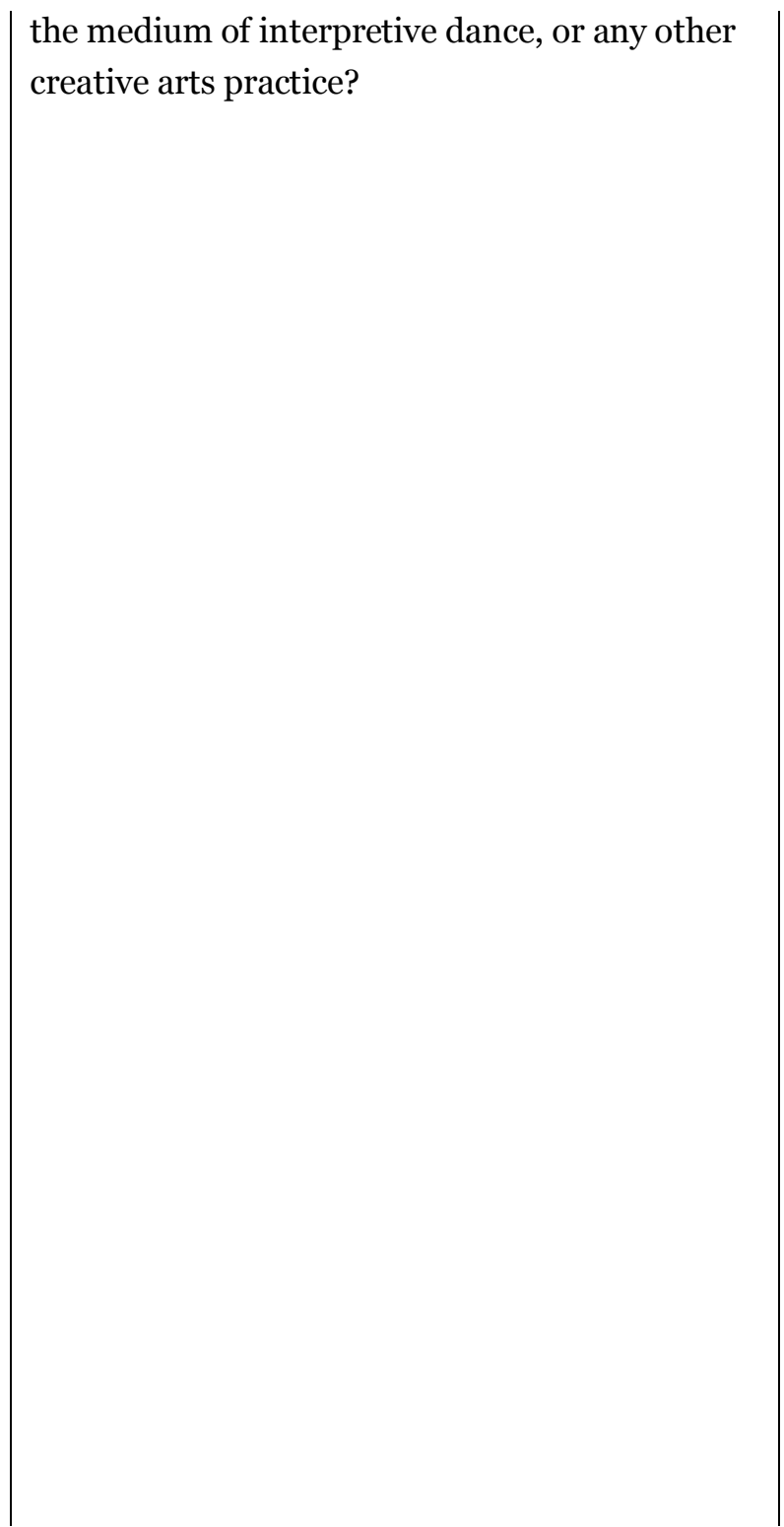

Wiley, Christopher. 2019. Autoethnography, autobiography, and creative art as academic research in music studies: A fugal ethnodrama. Action, Criticism, and Theory for Music Education 18 (2): 73-115. http://dx.doi.org/10.22176/act18.2.73 
music apparently cannot stand up on its own in such matters.

Absolutely-and that relates directly to your earlier question, Ed, about whether your songs themselves might reflect autoethnography, or whether such a line of argument would extend only as far as your lyrics. While there has been some welcome recognition recently that specific musical works might constitute autoethnographies in their own right (e.g., Hollingworth 2018), it does trouble me that such an understanding is too often predicated on the texts associated with them. What I'd really like to see is a musical work, with no referents beyond the music itself, that is nonetheless interpretable as autoethnography-for example, a purely instrumental piece. As you point out, who could say what that really means?

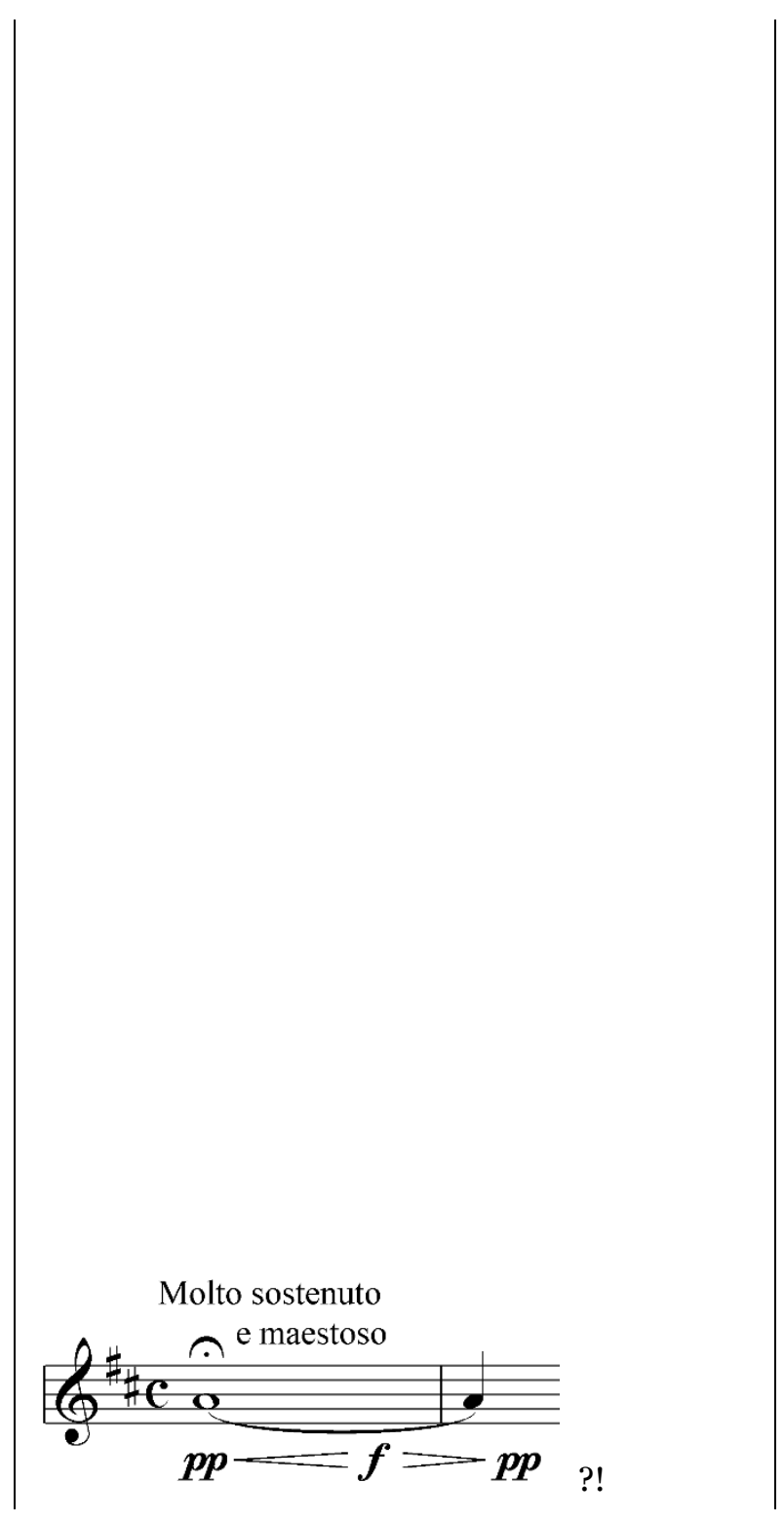

I'd imagine that another perennial stumbling-block is the evergreen question as to what music means, whether it means the same thing to different cultural communities, and, indeed, whether it can even be said to mean anything "concrete" at all.

Wiley, Christopher. 2019. Autoethnography, autobiography, and creative art as academic research in music studies: A fugal ethnodrama. Action, Criticism, and Theory for Music Education 18 (2): 73-115. http://dx.doi.org/10.22176/act18.2.73 
Not at all: as a comrade in arms in championing autoethnography has pointed out, the "graphy" [graphi] of "autoethnography" is "much more than writing text-the term can also be applied to drawing a picture [zographikì tèchni] and composing music [gràphontas musici]" (Gouzouasis 2017, 241). And of course a/r/tography (e.g., Gouzouasis 2006; Gouzouasis 2007) hybridizes various different modes of "writing" as research. So it's really a question of how, going forward, musicians might respond to the challenges of composing musical autoethnographies!

\section{[Coda: subject]}

But for music (or any creative artwork) to be successful as autoethnography, referring back to my initial definition, there would need to be some means of satisfactorily articulating
Quite. As Cooke $(1959,27)$ asks in his foundational text The Language of Music, what does it mean for the solo trumpet at the opening of Wagner's Rienzi to sound a single note, getting louder and then softer, without any other contextual associations to ground the listener?
Not wishing to open up another debate we don't have time for, but does that mean that we can never realistically reach the stage at which music is recognized as autoethnography? 
the relationship between the individual and their culture such that it is accurately communicated to the "reader."

Well, it strikes me that it would certainly be difficult to undertake successfully without incorporating an explanatory textual commentary. In fact, my original idea for this journal special issue was to devise a musical "composition" intended to be "read" rather than "played" (but without any accompanying commentary), but I very quickly abandoned it as I couldn't conceive of a way of unambiguously presenting educational research successfully through such a medium.

\section{[Countersubject]}

Where does that leave our discussion, then? While we've talked about the range of documents that might in principle be considered viable for an autoethnography, I'm still a little unsure how a study constructed along these lines that employed a non-conventional medium such as music would really work in practice. I'm not convinced that it's even possible to explore the ground you propose without recourse to prose commentary.
At least autoethnography's emphasis on the single-subject study is served well by art.

There's a long-standing debate as to the extent to which music is necessarily autobiographical; but the point remains that invariably there is an intimate relationship

Wiley, Christopher. 2019. Autoethnography, autobiography, and creative art as academic research in music studies: A fugal ethnodrama. Action, Criticism, and Theory for Music Education 18 (2): 73-115. http://dx.doi.org/10.22176/act18.2.73 
And I'd have said that at some level, the relationship between a musical composition and the culture in which it is cultivated is at least implicit in the end product. The relationship between your songs, Ed, and the popular music of the day will be reflected in what you write; just as a strong grounding in Western art-music would be evident in contemporary "classical" compositions. It could hardly be otherwise, since it simply isn't possible for creative artists to remove themselves completely from their time and place of origin, which conditions if not defines their art; it relates to Anna's earlier point about authors being implicated in their work. As we discussed, their output would not constitute autoethnography by that token alone: in order to make the transition from autobiography, it would need to move beyond mere life-writing of the self and establish both a relationship to its originating culture and a relatability with its proposed readership. But perhaps, following Gouzouasis (cited above), it offers something of a way forward for the potential of music as autoethnography, in addition to

between the output and its creator. Autoethnography may be more than merely autobiography-I'm persuaded by that now-but it has to start with autobiography, and therefore to provide a robust reflection of the subject.

Wiley, Christopher. 2019. Autoethnography, autobiography, and creative art as academic research in music studies: A fugal ethnodrama. Action, Criticism, and Theory for Music Education 18 (2): 73-115. http://dx.doi.org/10.22176/act18.2.73 
autobiography-even if a written commentary might nonetheless be needed to spell out that relationship for the reader or listener, to save them having to undertake the work of drawing the connections themselves.

I have an idea-shall we all go down to The Horse and Jockey to continue the conversation? Our friends from the sciences will doubtless be there shortly after their day in the labs. Let's see if we can convince them of the virtues of PhDs in the arts and humanities! 


\begin{abstract}
About the Author
Christopher Wiley is Senior Lecturer in Music at the University of Surrey. As a musicologist, he is the author of journal articles published in The Musical Quarterly, Music \& Letters, and Comparative Criticism, in addition to book chapters on subjects as wideranging as Haydn, Ethel Smyth, Michael Jackson, and the score of Buffy the Vampire Slayer. He is currently preparing a monograph on the earliest volumes of the "Master Musicians" series (1899-1906), as well as developing several co-edited volumes including one provisionally entitled Writing About Personal Experience as Academic Research in Music Studies: Autoethnography, Self-Reflexivity, and Arts-Based Practice. Chris also pursues pedagogic research in relation to higher education, with research interests in electronic voting systems, assessment and feedback, student evaluation of teaching, and autoethnography. This work has appeared in publications including Arts \& Humanities in Higher Education, Pedagogic Frailty and Resilience in the University, and The International Journal of Assessment and Evaluation. Chris holds postgraduate degrees in both Music and Academic Practice; he was awarded a National Teaching Fellowship in 2013, and became a Principal Fellow of the Higher Education Academy in 2017. Website: https://www.surrey.ac.uk/people/christopher-wiley
\end{abstract}

\title{
References
}

Anderson, Leon. 2006. Analytic autoethnography. Journal of Contemporary Ethnography 35 (4): 373-95.

Austin, Jon, and Andrew Hickey. 2007. Autoethnography and Teacher Development. The International Journal of Interdisciplinary Social Sciences, 2: http://eprints.usq.edu.au/3287/.

Bakhtin, Mikhail. 1984. Problems of Dostoevsky's poetics (ed. and trans. by C. Emerson). Minneapolis: University of Minnesota Press.

Banks, Stephen P., and Anna Banks. 2000. Reading “The critical life": Autoethnography as pedagogy. Communication Education 49 (3): 233-8. DOI:

10.1080/03634520009379212

Becher, Tony, and Paul R. Trowler. 2001. Academic tribes and territories: Intellectual enquiry and the culture of disciplines, 2nd ed. Buckingham: The Society for Research into Higher Education and Open University Press.

Belbase, Shashidhar, Bal Chandra Luitel, and Peter Charles Taylor. 2008. Autoethnography: A method of research and teaching for transformative education. Journal of Education and Research 1 (1): 86-95.

Bochner, Arthur P., and Carolyn Ellis. 2016. Evocative autoethnography: Writing lives and telling stories. New York: Routledge.

Wiley, Christopher. 2019. Autoethnography, autobiography, and creative art as academic research in music studies: A fugal ethnodrama. Action, Criticism, and Theory for Music Education 18 (2): 73-115.

http://dx.doi.org/10.22176/act18.2.73 
Campbell, Elaine. 2017. "Apparently being a self-obsessed $\mathrm{c}^{* *} \mathrm{t}$ is now academically lauded": Experiencing Twitter trolling of autoethnographers. Forum Qualitative Sozialforschung / Forum: Qualitative Social Research 18 (3): http://www.qualitative-research.net/index.php/fqs/article/view/2819. DOI: 10.17169/fqs-18.3.2819

Chang, Heewon. 2008. Autoethnography as method. Walnut Creek, CA: Left Coast.

Chang, Heewon, Faith Wambura Ngunjiri, and Kathy-Ann C. Hernandez. 2013. Collaborative autoethnography. Walnut Creek, CA: Left Coast.

Cook, Nicholas. 1998. Music: A very short introduction. Oxford: Oxford University Press.

Cooke, Deryck. 1959. The language of music. London: Oxford University Press.

Croft, John. 2015. Composition is not research. Tempo 69 (272): 6-11. DOI: $10.1017 /$ So040298214000989

Ellis, Carolyn. 2012. Revisioning an ethnographic life: Integrating a communicative heart with a sociological eye. In Blue-ribbon papers: Behind the professional mask: The autobiographies of leading symbolic interactionists. Studies in Symbolic Interaction, Volume 38, edited by N.K. Denzin, 123-51. [Bingley]: Emerald. DOI: 10.1108/So163-2396(2012)0000038009

Ellis, Carolyn, Toney E. Adams, and Arthur P. Bochner. 2011. Autoethnography: An Overview. Forum Qualitative Sozialforschung / Forum: Qualitative Social Research 12 (1): http://www.qualitative-research.net/index.php/fqs/article/view/1589/3096.

Ellis, Carolyn, and Arthur P. Bochner. 2000. Autoethnography, personal narrative, reflexivity: Researcher as subject. In Handbook of qualitative research, edited by N.K. Denzin and Y.S. Lincoln, 733-68. Thousand Oaks, CA: Sage.

Etherington, Kim. 2004. Becoming a reflexive researcher: Using our selves in research. London: Kingsley.

Gouzouasis, Peter. 2006. A/r/tography in music research: A reunification of musician, researcher, and teacher. Arts and Learning Research Journal 22 (1): 23-42.

Gouzouasis, Peter. 2007. Music in an a/r/tographic tonality. Journal of the Canadian Association for Curriculum Studies 5 (2): 33-59.

Gouzouasis, Peter. 2008. Toccata on assessment, validity and interpretation. In Being with a/r/tography, edited by Stephanie Springgay, Rita L. Irwin, Carl Leggo, and Peter Gouzouasis, 219-30. Rotterdam: Sense.

Wiley, Christopher. 2019. Autoethnography, autobiography, and creative art as academic research in music studies: A fugal ethnodrama. Action, Criticism, and Theory for Music Education 18 (2): 73-115.

http://dx.doi.org/10.22176/act18.2.73 
Gouzouasis, Peter. 2017. A/r/tographic inquiry in a new tonality: The relationality of music and poetry. In Handbook of arts-based research, edited by Patricia Leavy, 233-46. New York: Guilford.

Gouzouasis, Peter, and Danny Bakan. 2018. Arts-based educational research in community music. In The Oxford handbook of community music, edited by Brydie-Leigh Bartleet and Lee Higgins, 573-92. New York: Oxford University Press. DOI: 10.1093/oxfordhb/9780190219505.013.17

Gouzouasis, Peter, Danny Bakan, Jee Yeon Ryu, Helen Ballam, David Murphy, Diana Ihnatovych, Zoltan Virag, and Matthew Yanko. 2014. Where do teachers and learners stand in music education research? A multi-voiced call for a new ethos of music education research. International Journal of Education and the Arts 15 (15). http://www.ijea.org/v15n15/

Gouzouasis, Peter, Julia Henrey, and George Belliveau. 2008. Turning points: a transitional story of grade seven music students' participation in high school band programmes. Music Education Research 10 (1): 75-90. DOI: 10.1080/14613800701871397

Gouzouasis, Peter, and Karen V. Lee. 2002. Do you hear what I hear? Musicians composing the truth. Teacher Education Quarterly 29 (4): 125-41.

Healey, Mick, Abbi Flint, and Kathy Harrington. 2014. Engagement through partnership: students as partners in learning and teaching in higher education. Heslington, York: Higher Education Academy. https://www.heacademy.ac.uk/system/files/resources/engagement_through_partnership.pdf

Hockey, Jenny, and Martin Forsey. 2012. Ethnography is not participant observation: Reflections on the interview as participatory qualitative research. In The interview: An ethnographic approach, edited by J. Skinner, 69-87. New York: Berg.

Hollingworth, Lucy. 2018. Storytelling in autoethnography-The poetess. Paper presented at "Beyond 'Mesearch': Autoethnography, self-reflexivity, and personal experience as academic research in music studies," Institute of Musical Research, London, UK, 16-17 April.

Ingold, Tim. 2014. That's enough about ethnography! HAU: Journal of Ethnographic Theory 4 (1): 383-95. DOI: 10.14318/hau4.1.021

Jackson, Michael. 1989. Paths toward a clearing: Radical empiricism and ethnographic inquiry. Bloomington: Indiana University Press.

Wiley, Christopher. 2019. Autoethnography, autobiography, and creative art as academic research in music studies: A fugal ethnodrama. Action, Criticism, and Theory for Music Education 18 (2): 73-115.

http://dx.doi.org/10.22176/act18.2.73 
Kinchin, Ian M., and Christopher Wiley. 2018. Tracing pedagogic frailty in arts and humanities education: An autoethnographic perspective. Arts and Humanities in Higher Education: An international journal of theory, research, and practice 17 (2): 241-64. DOI: 10.1177/1474022217698082

Lee, Karen V. 2006. A fugue About Grief. Qualitative Inquiry 12(6): 1154-9. DOI: 10.1177/1077800406293235

Nelson, Robin. 2013. Practice as research in the arts: Principles, protocols, pedagogies, Resistances. Basingstoke: Palgrave Macmillan.

Norris, Joe, Richard D. Sawyer, and Darren E. Lund, eds. 2012. Duoethnography: Dialogic methods for social, health, and educational research. Walnut Creek, CA: Left Coast.

Pace, Ian. 2016. Composition and performance can be, and often have been, research. Tempo 70 (275): 60-70. DOI: 10.1017/So040298215000637

Park, Chris. 2007. Redefining the doctorate. Heslington, York: Higher Education Academy. https://www.heacademy.ac.uk/system/files/redefining_the_doctorate.pdf

Pelias, Ronald J. 2000. The critical life. Communication Education 49 (3): 220-28. DOI: $10.1080 / 03634520009379210$

Pelias, Ronald J. 2004. A methodology of the heart: Evoking academic and daily life. Walnut Creek, CA: AltaMira.

Pelias, Ronald J. 2005. Performative writing as scholarship: An apology, an argument, an anecdote. Cultural Studies-Critical Methodologies 5 (4): 415-24. DOI: $10.1177 / 1532708605279694$

Pelias, Ronald J. 2014. An autoethnographic writer's request to readers. International Review of Qualitative Research 7 (3): 279-82. DOI: 10.1525/irqr.2014.7.3.279

Pickles, Matt. 2017. "Mesearch"-when study really is all about me. BBC News, 10 May. https://www.bbc.co.uk/news/business-39856894

Richardson, Laurel. 1990. Writing strategies: Reaching diverse audiences. Thousand Oaks, CA: Sage.

Richardson, Laurel. 2000. Writing: A method of inquiry. In Handbook of qualitative research, edited by N.K. Denzin and Y.S. Lincoln, 923-948. Thousand Oaks, CA: Sage.

Vasconcelos, Erika França de Souza. 2011. "I can see you": An autoethnography of my teacher-student self. The Qualitative Report 16 (2): 415-40. http://www.nova.edu/ssss/QR/QR16-2/vasconcelos.pdf 
Wiley, Christopher. 2004. "When a woman speaks the truth about her body": Ethel Smyth, Virginia Woolf, and the challenges of lesbian auto/biography. Music \& Letters 85 (3): 388-414. DOI: $10.1093 / \mathrm{ml} / 85 \cdot 3 \cdot 388$

Wiley, Christopher. 2008. Re-writing composers' lives: Critical historiography and musical biography, 2 Vols. PhD diss., University of London. https://repository.royalholloway.ac.uk/items/51c986f5-ea02-d3b8-03e2-6ab2b962a61f/1/

Wiley, Christopher. 2011. Theorizing television music as serial art: Buffy the Vampire Slayer and the narratology of thematic score. In Buffy, ballads, and bad guys who sing: Music in the worlds of Joss Whedon, edited by Kendra Preston Leonard, 2973. Lanham, MD: Scarecrow.

Wiley, Christopher. 2014a. Academic leadership in learning and teaching in higher education: A personal reflection on one programme director's professional development. Learning at City Journal 4(2): 39-49.

http://openaccess.city.ac.uk/4896/1/L\%40C_Journal_Volume_4_Number_2__Article_4.pdf

Wiley, Christopher. 2014b. Divided by a common language? Evaluating students' understanding of the vocabulary of assessment and feedback at a single UK higher education institution. The International Journal of Assessment and Evaluation 20 (3): 111.

Wiley, Christopher. 2015. Using electronic voting systems in the arts and humanities. Heslington, York: Higher Education Academy. https://www.heacademy.ac.uk/system/files/dr_chris_wiley_final.pdf

Wiley, Christopher. 2017. Subject and countersubject: The prevalence of the genius and the muse in musical biography. Paper presented at "Beyond Genius and Muse: Collaborating Couples in Twentieth-Century Arts," University of Bristol, UK, 18-19 April.

Wiley, Christopher. (forthcoming). Biography and life-writing. In The Oxford handbook of music and intellectual culture in the nineteenth century, edited by Paul Watt, Sarah Collins, and Michael Allis. Oxford: Oxford University Press.

Wiley, Christopher. (in review). Exploring the integration of teaching and research in the contemporary classroom: An autoethnographic enquiry into designing an undergraduate music module on Adele's 25 album.

Wiley, Christopher, and Jo Franklin. 2017. Framed autoethnography and pedagogic frailty: A comparative analysis of mediated concept maps. In Pedagogic frailty and resilience in the university, edited by I.M. Kinchin and N.E. Winstone, 17-32. Rotterdam: Sense.

Wiley, Christopher. 2019. Autoethnography, autobiography, and creative art as academic research in music studies: A fugal ethnodrama. Action, Criticism, and Theory for Music Education 18 (2): 73-115.

http://dx.doi.org/10.22176/act18.2.73 
Wood, Elizabeth. 1993. Lesbian fugue: Ethel Smyth's contrapuntal arts. In Musicology and difference: Gender and sexuality in music scholarship, edited by Ruth A. Solie, 164-83. Berkeley: University of California Press.

\section{Note}

${ }^{1}$ In developing these lines of reasoning, I wish to acknowledge personally the value of discussions that have taken place over the years with my doctoral students, particularly Annie Yim, Ben Schoeman, Lucy Hollingworth, and Rachael Emmett (née Barnes), and with academic colleagues including Ian Kinchin, Peter Gouzouasis, Kirk Woolford, Jo Franklin, Tom Armstrong, Ian Pace, and my own PhD supervisor, Katharine Ellis. I would also like to thank my two anonymous reviewers for Action, Criticism, \& Theory for Music Education for their generous comments.

Wiley, Christopher. 2019. Autoethnography, autobiography, and creative art as academic research in music studies: A fugal ethnodrama. Action, Criticism, and Theory for Music Education 18 (2): 73-115.

http://dx.doi.org/10.22176/act18.2.73 